\title{
Quantum-chemical studies of rutile nanoparticles toxicity II. Comparison of B3LYP and PM6 data
}

\author{
Martin Breza \\ Department of Physical Chemistry, Faculty of Chemical and Food Technology, \\ Slovak University of Technology, Radlinského 9, 81237 Bratislava, Slovak Republic \\ martin.breza@stuba.sk \\ In the memory of Professor Rudolf Zahradnik (1928-2020).
}

\begin{abstract}
The relation between copper atomic charges and metal-ligand interaction energies obtained by PM6 and DFT-B3LYP methods for cytotoxicity prediction of model rutile nanoparticles $\left[\mathrm{Ti}_{40} \mathrm{O}_{124} \mathrm{H}_{81}\right]^{7-}$, $\left[\mathrm{Ti}_{7} \mathrm{O}_{28} \mathrm{H}_{26}\right]^{2-},\left[\mathrm{Ti}_{2} \mathrm{O}_{10} \mathrm{H}_{10}\right]^{2-},\left[\mathrm{Ti}_{7} \mathrm{O}_{30} \mathrm{H}_{30}\right]^{2-}$ and their $\mathrm{Cu}(\mathrm{II})$ complexes is investigated. Except for Mulliken charges, very good statistical parameters were obtained for the linear relation between the results obtained by both methods if standard accuracy of quantum-chemical calculations is achieved.
\end{abstract}

Keywords: DFT - B3LYP and PM6 methods, linear regression, metal-ligand interaction energy, population analyses, statistical parameters

\section{Introduction}

Biochemical and molecular mechanisms of cytotoxicity include oxidative stress-induced cellular events and alteration of the pathways pertaining to intracellular calcium homeostasis (Huang et al., 2017). Physicochemical properties of nanoparticles (surface, size, morphology, dissolution of ions etc.) influence their interaction with cells and, thus, their overall potential toxicity. Their shape also affects the levels of toxicity. In general, rod shaped nanoparticles are more toxic than the spherical ones (Hsiao and Huang, 2011; Lee et al., 2014; Forest et al., 2017). However, the reason of this phenomenon has not been fully elucidated yet.

Theoretical model studies based on quantumchemical calculations are capable to shed more light on this phenomenon. Cytotoxicity of nanoparticles can be predicted using the method originally elaborated for the estimation of relative activity of antioxidants (Alagona and Ghio, 2009a, 2009b; Mammino, 2013; Tsiepe et al., 2015; Puškárová and Breza, 2016, 2017; Jelemenská and Breza, 2021) based on their copper coordination ability (metal ion affinity, MIA) and electron density transfer to a hypothetical $\mathrm{Cu}(\mathrm{II})$ probe. According to this method, spin density of the $\mathrm{Cu}^{2+}$ cation upon ligand coordination decreases whereas the ligand spin density approaches 1 . Thus, the ligand is oxidized to a radical cation (Ligand ${ }^{*}$ ) while $\mathrm{Cu}(\mathrm{II})$ is reduced to $\mathrm{Cu}(\mathrm{I})$. In agreement with experimental investigations, the higher antioxidant activity of individual compounds and their reaction sites can be attrib- uted to higher MIA values and higher reducing character towards $\mathrm{Cu}(\mathrm{II})$.

Using the semiempirical PM6 method, the above treatment was used in the toxicity study (Breza and Simon, 2019) of the $\left[\mathrm{Ti}_{40} \mathrm{O}_{124} \mathrm{H}_{81}\right]^{7-}$ model cluster based on an idealized rod-like $\left[\mathrm{Ti}_{40} \mathrm{O}_{124}\right]^{88-}$ structure of ca $1.5 \mathrm{~nm} \times 1 \mathrm{~nm} \times 1 \mathrm{~nm}$ in size with all monovalent $\mathrm{O}$ atoms being protonated. Its planes are significantly deformed due to protonation and the original $\mathrm{Ti}$ hexacoordination is sometimes reduced to pentacoordination. Relative toxicity of individual $\mathrm{Ti}$ centers in this rutile nanoparticle, as evaluated by the electron density transfer to a $\mathrm{Cu}^{2+}$ probe, has maximal values at the pentacoordinated corner and hexacoordinated edge $\mathrm{Ti}$ centers with three $\mathrm{Ti}-\mathrm{OH}$ bonds. However, these centers exhibit the lowest negative interaction energies which can be compensated by the significantly better accessibility of the corner Ti center compared with that of the remaining ones. Ti centers with the most negative interaction energy parameters exhibit the lowest extent of electron density transfer to the $\mathrm{Cu}^{2+}$ probe. Rutile nanoparticles destruction starts at the pentacoordinated Ti face centers.

According to B3LYP calculations (Breza and Šimon, 2020), electron density removal from model rutile nanoparticles, such as spherical ${ }^{1}\left[\mathrm{Ti}_{7} \mathrm{O}_{28} \mathrm{H}_{26}\right]^{2-}, \quad{ }^{1}\left[\mathrm{Ti}_{2} \mathrm{O}_{10} \mathrm{H}_{10}\right]^{2-}$ and rod-like ${ }^{1}\left[\mathrm{Ti}_{7} \mathrm{O}_{30} \mathrm{H}_{30}\right]^{2-}$, is accompanied with significant changes in their structure and may cause their degradation. Terminal hydroxyls seem to be more reactive than the bridging ones as indicated by their interaction energies. Spherical structures are more reactive than the rod-like chains of (nearly) 
the same size. Reverse relation holds for the degree of their toxicity as indicated by the extent of electron density transfer to the $\mathrm{Cu}^{2+}$ probe. The experimentally observed higher cytotoxicity of the rod-like nanoparticles in comparison with the spherical ones (see above) can be explained by the higher electron density transfer to the interacting living cells.

Semiempirical methods of quantum chemistry are suitable for the study of large model systems (hundreds of atoms at our available facilities). On the other hand, they are believed, in general, to be less accurate than the ab initio or DFT methods. Therefore, the question arises whether the results - or, more exactly, their trends - obtained by both above mentioned studies (Breza and Šimon, 2019, 2020) are comparable. In our recent study, the results (atomic charges and interaction energies) obtained by the PM6 method are re-calculated at the B3LYP level of theory and vice versa. Due to technical reasons, fixed original geometries of the systems under study are used for our quantumchemical calculations. The aim of our study is to compare the trends in the data obtained at both levels of theory for the same geometries of the systems under study.

\section{Method}

Single point calculations of the PM6 optimized geometries (Breza and Šimon, 2019) of ${ }^{1}\left[\mathrm{Ti}_{40} \mathrm{O}_{124} \mathrm{H}_{81}\right]^{7-}$ and ${ }^{2}\left[\mathrm{Ti}_{40} \mathrm{O}_{124} \mathrm{H}_{81} \mathrm{Cu}\right]^{5-}$ (model I series, denoted by spin multiplicity as the left superscript) were performed at the DFT level of theory using B3LYP hybrid functional (Becke, 1993) with standard LANL2DZ pseudopotentials and basis sets (Dunning, 1977; Hay and Wadt, 1985) for all atoms. Atomic charges were evaluated in terms of the Mulliken population analysis (MPA) (Mulliken, 1955) and natural population analysis (NPA) (Reed et al., 1988).

Single point calculations of the B3LYP optimized geometries (Breza and Šimon, 2020) of ${ }^{1}\left[\mathrm{Ti}_{7} \mathrm{O}_{28} \mathrm{H}_{26}\right]^{2-},{ }^{1}\left[\mathrm{Ti}_{2} \mathrm{O}_{10} \mathrm{H}_{10}\right]^{2-},{ }^{1}\left[\mathrm{Ti}_{7} \mathrm{O}_{30} \mathrm{H}_{30}\right]^{2-}$, ${ }^{2}\left[\mathrm{Ti}_{7} \mathrm{O}_{28} \mathrm{H}_{26} \mathrm{Cu}\right]^{0}, \quad{ }^{2}\left[\mathrm{Ti}_{2} \mathrm{O}_{10} \mathrm{H}_{10} \mathrm{Cu}\right]^{0}$ and ${ }^{2}\left[\mathrm{Ti}_{7} \mathrm{O}_{30} \mathrm{H}_{30} \mathrm{Cu}\right]^{0}$ (model II series) were performed at the semiempirical level of theory using the PM6 method (Stewart, 2007). Atomic charges were evaluated in terms of the Mulliken population analysis (MPA) (Mulliken, 1955).

All the above calculations were performed using the Gaussian09 program package (Frisch et al., 2013). Atomic polar tensor (APT) derived charges (Cioslowski, 1989) demand vibrational analysis to be performed and therefore are unusable in single point calculations. Metal-ligand interaction energy
$\Delta_{\text {int }} E$ is defined as

$$
\Delta_{\text {int }} E=E_{\text {Complex }-} E_{\mathrm{L}_{-}} E_{\text {ion }}
$$

where $E_{\text {Complex }}$ and $E_{\mathrm{L}}$ are energies of the ${ }^{2}[\mathrm{~L} \ldots \mathrm{Cu}]$ $\mathrm{q}^{+2}$ complex and of the isolated rutile nanoparticle ${ }^{1} \mathrm{~L}^{\mathrm{q}}$ model cluster, respectively, and $E_{\text {ion }}$ is energy of the isolated ${ }^{2} \mathrm{Cu}^{2+}$ ion (Alagona and Ghio, 2009a, 2009b; Mammino, 2013; Tsiepe et al., 2015; Puškárová and Breza, 2016, 2017; Jelemenska and Breza, 2021).

Similarity of the trends in the results obtained by both quantum-chemical methods can be evaluated by the linear relation:

$$
\mathrm{Y}=\mathrm{a}_{1} \mathrm{X}+\mathrm{a}_{0}
$$

where $\mathrm{X}$ and $\mathrm{Y}$ are values (i.e., atomic charges and interaction energies) obtained by PM6 and B3LYP methods, respectively, $\mathrm{a}_{1}$ and $\mathrm{a}_{0}$ are linear regression parameters. The goodness of fit is evaluated by standard statistical parameters such as the standard deviations of regression parameters and the coefficient of determination $\mathrm{R}^{2}$.

\section{Results and discussion}

\section{a) Model systems I}

In the ${ }^{1}\left[\mathrm{Ti}_{40} \mathrm{O}_{124} \mathrm{H}_{81}\right]^{7-}$ model cluster (Breza and Šimon, 2019), various Ti centers can be distinguished according to their bonding to hydroxyl groups $(\mathrm{OH})$ and bridging oxygens $\left(\mathrm{O}_{\mathrm{b}}\right)$ between two Ti atoms. These centers can be divided into three groups and their toxicity can be estimated by neighboring $\mathrm{Cu}^{2+}$ probes in the PM6 optimized ${ }^{2}\left[\mathrm{Ti}_{40} \mathrm{O}_{124} \mathrm{H}_{81} \mathrm{Cu}\right]^{5-}$ model systems as follows (Fig. 1):

i) At the rod corners, only pentacoordinated $\mathrm{Ti}(\mathrm{OH})_{3}\left(\mathrm{O}_{\mathrm{b}}\right)_{2}$ centers are found (model I-A).

ii) Rod edges contain either hexacoordinated $\mathrm{Ti}(\mathrm{OH})_{3}\left(\mathrm{O}_{\mathrm{b}}\right)_{3} \quad($ model I-B 1$), \quad \mathrm{Ti}(\mathrm{OH})_{2}\left(\mathrm{O}_{\mathrm{b}}\right)_{4}$ (model I-B2) and $\mathrm{Ti}(\mathrm{OH})\left(\mathrm{O}_{\mathrm{b}}\right)_{5}$ (model I-B3) centers or pentacoordinated $\mathrm{Ti}(\mathrm{OH})_{4}\left(\mathrm{O}_{\mathrm{b}}\right)$ (model I-B4), $\mathrm{Ti}(\mathrm{OH})_{3}\left(\mathrm{O}_{\mathrm{b}}\right)_{2}(\operatorname{model} \mathrm{I}-\mathrm{B} 5)$ and $\mathrm{Ti}(\mathrm{OH})_{2}\left(\mathrm{O}_{\mathrm{b}}\right)_{3}$ (model I-B6) centers.

iii) Rod faces have hexacoordinated $\mathrm{Ti}(\mathrm{OH})\left(\mathrm{O}_{\mathrm{b}}\right)_{5}$ (model I-C1) or pentacoordinated $\mathrm{Ti}(\mathrm{OH})\left(\mathrm{O}_{\mathrm{b}}\right)_{4}$ (model I-C2) centers.

Copper atomic charges and interaction energies of model systems I (Fig. 1) are presented in Figs. 2-4 and Table A1 of Appendix. It must be mentioned that DFT calculations of ${ }^{1}\left[\mathrm{Ti}_{40} \mathrm{O}_{124} \mathrm{H}_{81}\right]^{7-}$ and ${ }^{2}\left[\mathrm{Ti}_{40} \mathrm{O}_{124} \mathrm{H}_{81} \mathrm{Cu}\right]^{5-}$ systems face serious technical problems. It was not possible to obtain standard convergence accuracy $\left(10^{-8}\right.$ root-mean-square change in the density matrix). In most cases, the accuracy was reduced by one or two orders only but in two cases (I-B3 and I-C2 systems, denoted 


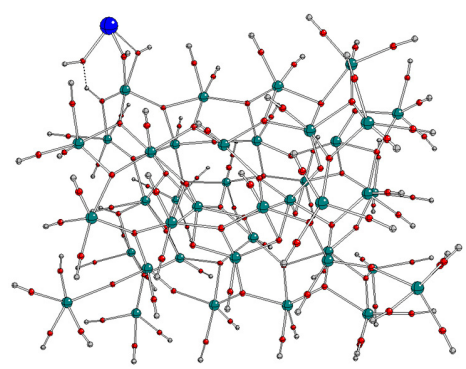

I-A

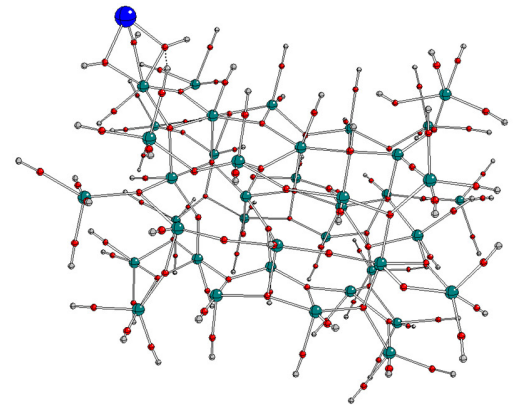

I-B 1

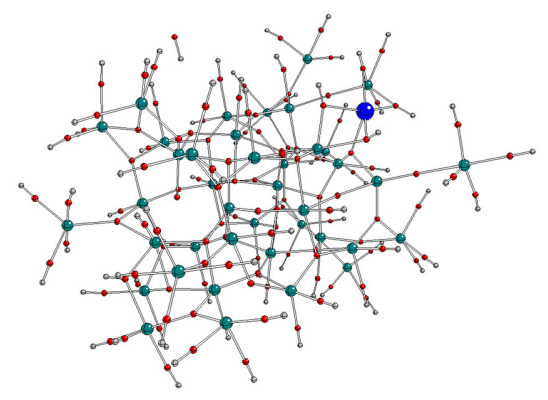

I-B3

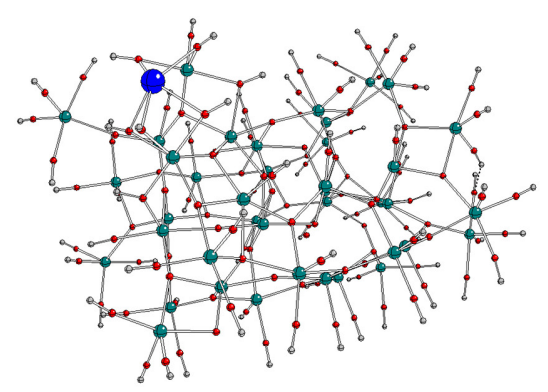

I-B 5

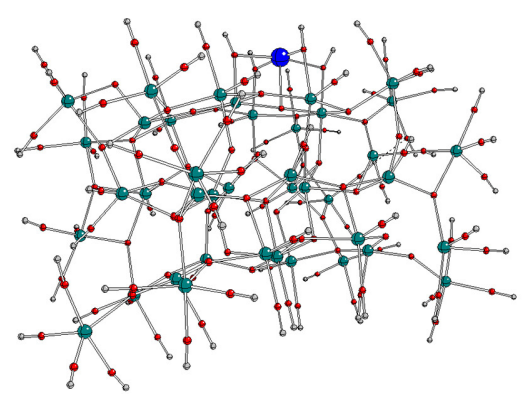

I-C 1

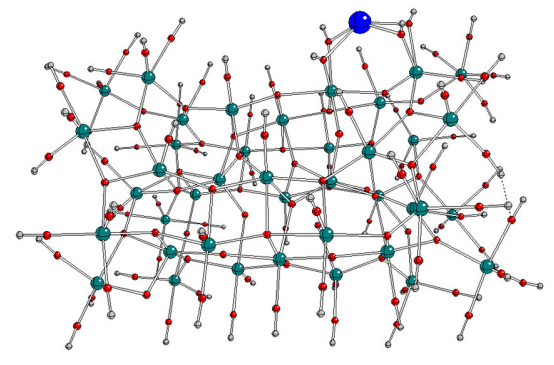

I-B2

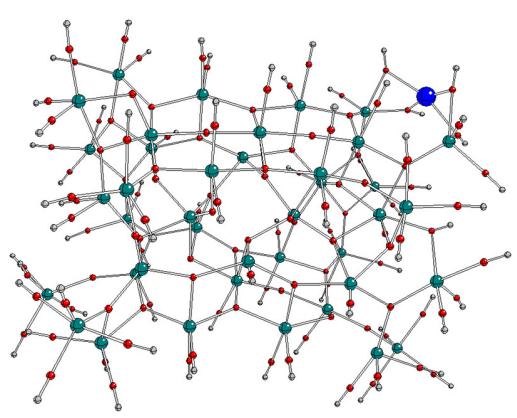

I-B4

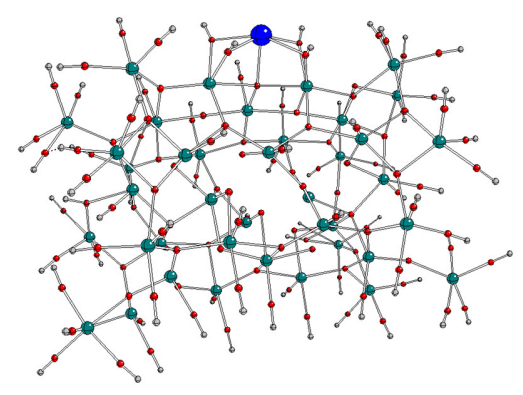

I-B6

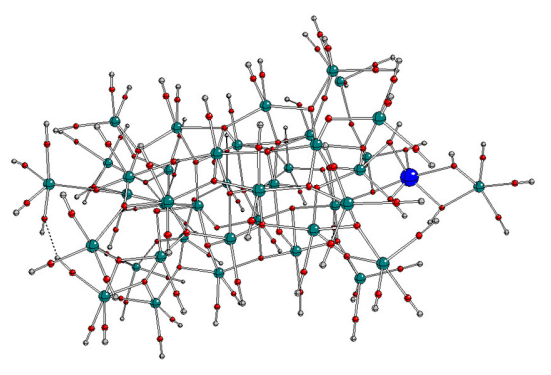

I-C2

Fig. 1. PM6 optimized geometries of $\left[\mathrm{Ti}_{40} \mathrm{O}_{124} \mathrm{H}_{81} \mathrm{Cu}\right]^{5-}$ model systems $(\mathrm{Ti}$ - green, $\mathrm{O}-$ red, $\mathrm{H}-$ grey, $\mathrm{Cu}$ - blue) (Breza and Šimon, 2019). 

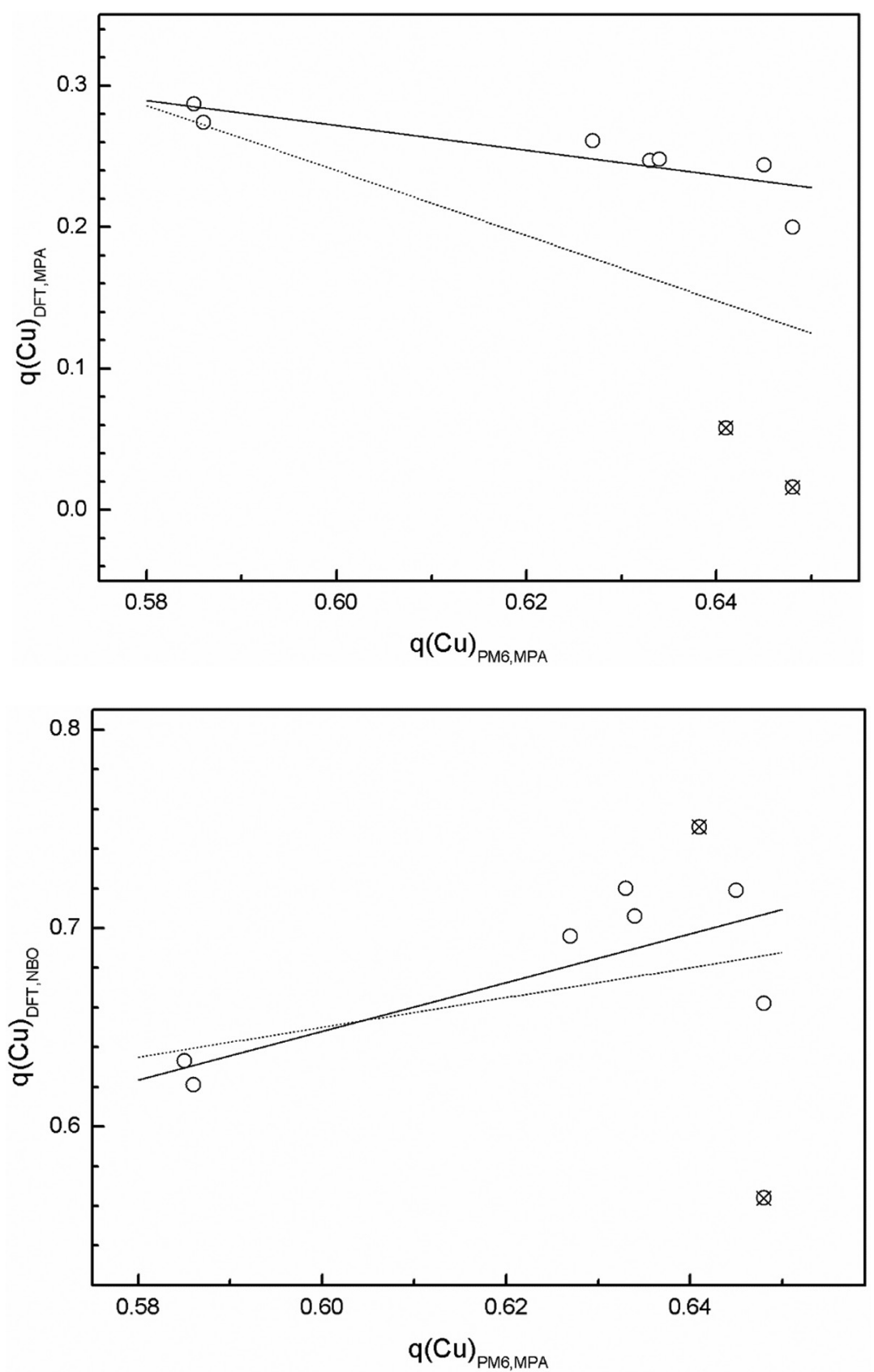

Fig. 2. Plots of MPA (top) and NBO (bottom) charges of $\mathrm{Cu}$ obtained by the DFT-B3LYP method vs MPA charges of $\mathrm{Cu}$ obtained by the PM6 method for ${ }^{2}\left[\mathrm{Ti}_{40} \mathrm{O}_{124} \mathrm{H}_{81} \mathrm{Cu}\right]^{5-}$ systems. Dashed and full lines correspond to linear regression for all systems and for all but I-B3 and I-C2 systems (crossed circles), respectively.

by crossed circles in Figs. 2-4), accuracy reduction by four orders was achieved. Therefore, linear regression according to Eq. (2) is presented for all systems and, alternatively, if the two least accurate systems were omitted.

Unlike the NBO charges of copper atoms obtained at the B3LYP level of theory, the MPA ones exhibit reverse trends and decrease with the increasing MPA and APT charges obtained by the semiempirical PM6 method (Table 1, Figs. 2-3). Nevertheless, poor statistical parameters contradict to possible proportionality between copper charges obtained at both levels of theory within the model systems of the I series.

Interaction energy data obtained by the B3LYP and PM6 methods show correct trend only after omitting two least accurate results (I-B3 and I-C2 systems) but their relation also exhibits poor statistical parameters (Table 1, Figs. 4).

Poor statistical parameters of the ${ }^{2}\left[\mathrm{Ti}_{40} \mathrm{O}_{124} \mathrm{H}_{81} \mathrm{Cu}\right]^{5-}$ systems can be partially ascribed to insufficient accuracy of their B3LYP calculations. Small charge 

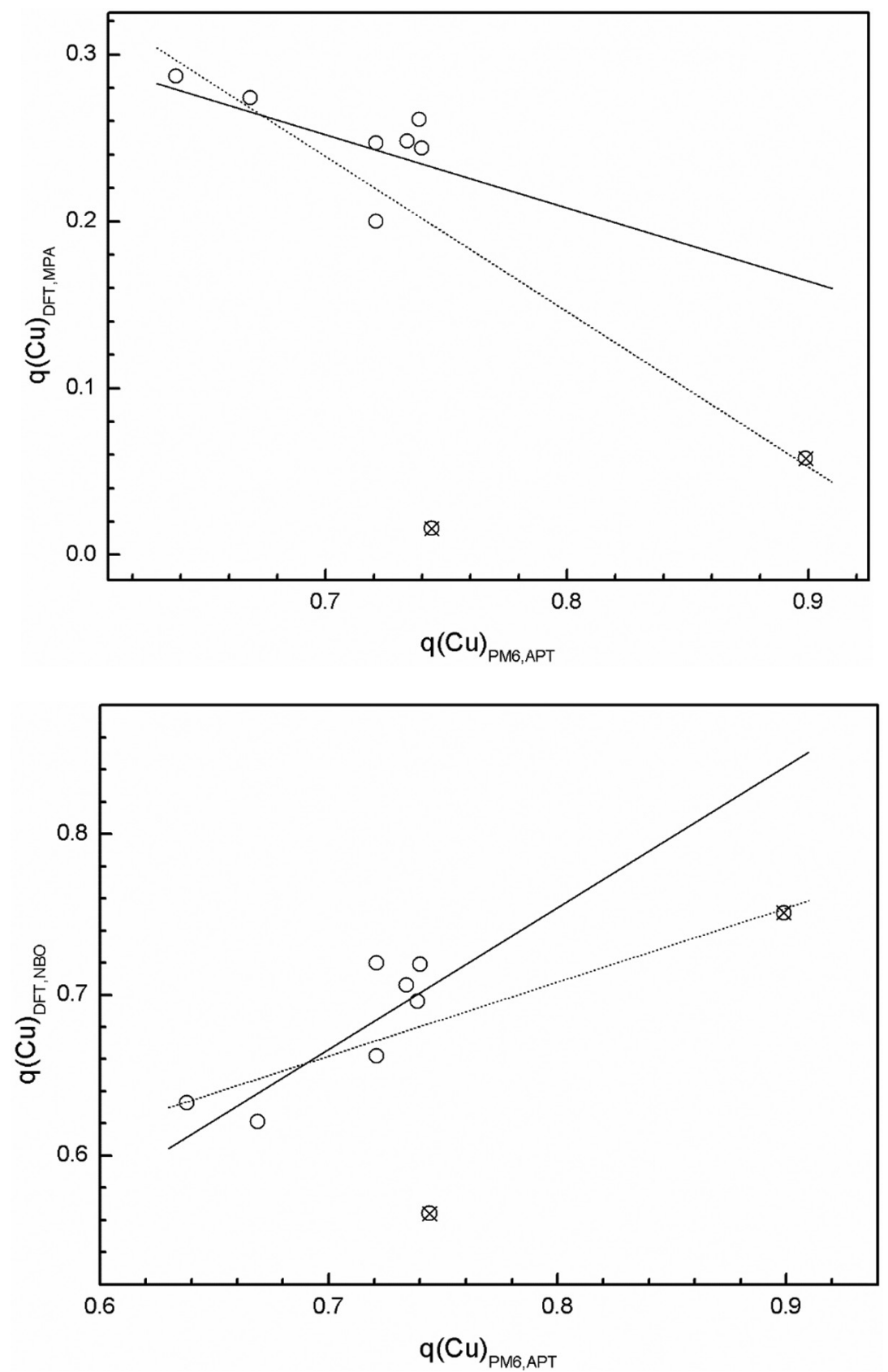

Fig. 3. Plots of MPA (top) and NBO (bottom) charges of Cu obtained by the DFT-B3LYP method vs APT charges of $\mathrm{Cu}$ obtained by the PM6 method for ${ }^{2}\left[\mathrm{Ti}_{40} \mathrm{O}_{124} \mathrm{H}_{81} \mathrm{Cu}\right]^{5-}$ systems. Dashed and full lines correspond to linear regression for all systems and for all but I-B3 and I-C2 systems (crossed circles), respectively.

and interaction energy differences between individual model systems near their accuracy limits contribute to the trend looseness as well.

\section{b) Model systems II}

The nearly spherical structure of ${ }^{1}\left[\mathrm{Ti}_{7} \mathrm{O}_{28} \mathrm{H}_{26}\right]^{2-}$ (Breza and Šimon, 2020) consists of a single $\mathrm{TiO}_{6}$ octahedron surrounded by six lateral $\mathrm{TiO}_{6}$ octahedra. In ${ }^{2}\left[\mathrm{Ti}_{7} \mathrm{O}_{28} \mathrm{H}_{26} \mathrm{Cu}\right]^{0}$ model systems, the $\mathrm{Cu}^{2+}$ ion is next to the terminal hydroxyl (model II-Ala) or the bridging hydroxyl (models II-A2a and II-A2b) groups (see Fig. 5).

Rod-like chain structures ${ }^{1}\left[\mathrm{Ti}_{2} \mathrm{O}_{10} \mathrm{H}_{10}\right]^{2-}$ and ${ }^{1}\left[\mathrm{Ti}_{7} \mathrm{O}_{30} \mathrm{H}_{30}\right]^{2-}$ (Breza and Šimon, 2020) consist of $\mathrm{TiO}_{6}$ octahedra bound by double $\mu-\mathrm{OH}$ bridges as the single bridged structures disintegrate after protonation. In the dimeric ${ }^{2}\left[\mathrm{Ti}_{2} \mathrm{O}_{10} \mathrm{H}_{10} \mathrm{Cu}\right]^{0}$ and heptameric ${ }^{2}\left[\mathrm{Ti}_{7} \mathrm{O}_{30} \mathrm{H}_{30} \mathrm{Cu}\right]^{0}$ chains, the $\mathrm{Cu}^{2+}$ ion is placed next to the terminal hydroxyl (models II-B 1a to II-B 1c, and II-Cla to II-C1h) or the bridg- 


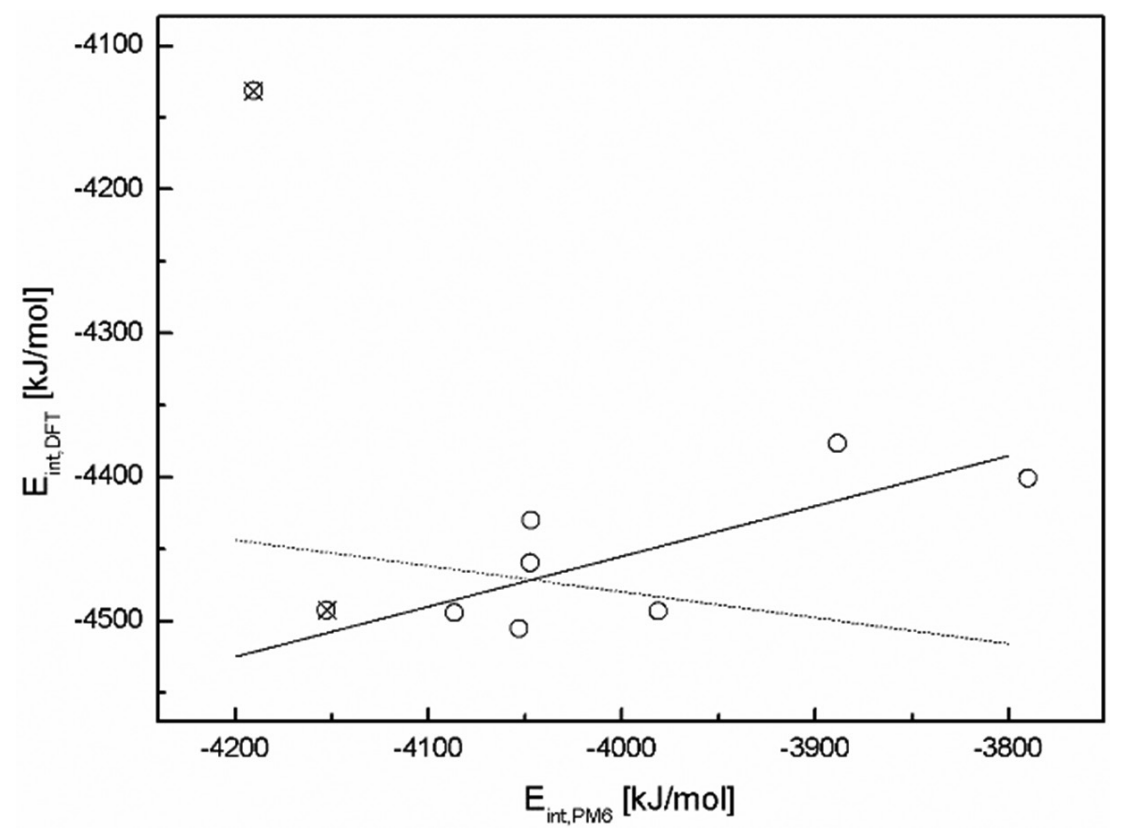

Fig. 4. Plot of interaction energies obtained by the DFT-B3LYP method vs the PM6 method for ${ }^{2}\left[\mathrm{Ti}_{40} \mathrm{O}_{124} \mathrm{H}_{81} \mathrm{Cu}\right]^{5-}$ systems. Dashed and full lines correspond to linear regression for all systems and for all but I-B3 and I-C2 systems (crossed circles), respectively.

Tab. 1. Regression parameters $\left(a_{1}, a_{0}\right)$ of Eq. (2) with standard deviations for model systems I (see Fig. 1) and the coefficient of determination $\left(\mathrm{R}^{2}\right)$ for the dataset consisting of $\mathrm{N}$ components.

\begin{tabular}{|c|c|c|c|c|c|}
\hline $\mathrm{N}$ & $\mathrm{Y}$ & $\mathrm{X}$ & $a_{1}$ & $\mathrm{a}_{0}$ & $\mathrm{R}^{2}$ \\
\hline \multirow[t]{5}{*}{9} & $\mathrm{q}(\mathrm{Cu})_{\mathrm{DFT}, \mathrm{MPA}}$ & $\mathrm{q}(\mathrm{Cu})_{\mathrm{PM} 6, \mathrm{MPA}}$ & $-2.3 \pm 1.2$ & $1.62 \pm 0.77$ & 0.23063 \\
\hline & $\mathrm{q}(\mathrm{Cu})_{\mathrm{DFT}, \mathrm{NBO}}$ & $\mathrm{q}(\mathrm{Cu})_{\mathrm{PM} 6, \mathrm{MPA}}$ & $0.75 \pm 0.86$ & $0.20 \pm 0.54$ & 0.02964 \\
\hline & $\mathrm{q}(\mathrm{Cu})_{\mathrm{DFT}, \mathrm{MPA}}$ & $\mathrm{q}(\mathrm{Cu})_{\mathrm{PM} 6, \mathrm{APT}}$ & $-0.93 \pm 0.38$ & $0.89 \pm 0.28$ & 0.39006 \\
\hline & $\mathrm{q}(\mathrm{Cu})_{\mathrm{DFT}, \mathrm{NBO}}$ & $\mathrm{q}(\mathrm{Cu})_{\mathrm{PM} 6, \mathrm{APT}}$ & $0.46 \pm 0.26$ & $0.34 \pm 0.19$ & 0.20839 \\
\hline & $\mathrm{E}_{\mathrm{int,DFT}}$ & $\mathrm{E}_{\mathrm{int}, \mathrm{PM} 6}$ & $-0.18 \pm 0.35$ & $-5200 \pm 1400^{\mathrm{b})}$ & 0.09858 \\
\hline \multirow[t]{5}{*}{$7^{\text {a) }}$} & $\mathrm{q}(\mathrm{Cu})_{\mathrm{DFT}, \mathrm{MPA}}$ & $\mathrm{q}(\mathrm{Cu})_{\mathrm{PM} 6, \mathrm{MPA}}$ & $-0.88 \pm 0.25$ & $0.80 \pm 0.16$ & 0.64979 \\
\hline & $\mathrm{q}(\mathrm{Cu})_{\mathrm{DFT}, \mathrm{NBO}}$ & $\mathrm{q}(\mathrm{Cu})_{\mathrm{PM} 6, \mathrm{MPA}}$ & $1.23 \pm 0.42$ & $-0.09 \pm 0.26$ & 0.55334 \\
\hline & $\mathrm{q}(\mathrm{Cu})_{\mathrm{DFT}, \mathrm{MPA}}$ & $\mathrm{q}(\mathrm{Cu})_{\mathrm{PM} G, A P T}$ & $-0.44 \pm 0.24$ & $0.56 \pm 0.17$ & 0.27226 \\
\hline & $\mathrm{q}(\mathrm{Cu})_{\mathrm{DFT}, \mathrm{NBO}}$ & $\mathrm{q}(\mathrm{Cu})_{\mathrm{PM} 6, \mathrm{APT}}$ & $0.88 \pm 0.24$ & $0.05 \pm 0.17$ & 0.67224 \\
\hline & $\mathrm{E}_{\text {int,DFT }}$ & $\mathrm{E}_{\mathrm{int}, \mathrm{PM} 6}$ & $0.35 \pm 0.14$ & $-3100 \pm 560^{b)}$ & 0.46067 \\
\hline
\end{tabular}

Remarks:

a) I-B4 and I-C2 models omitted

b) in $\mathrm{kJ} / \mathrm{mol}$ units

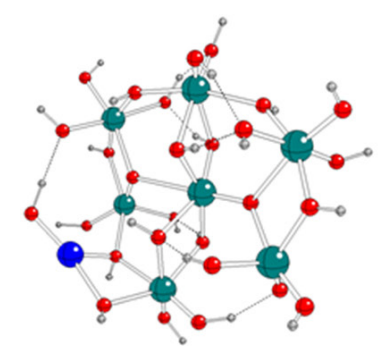

II-Ala

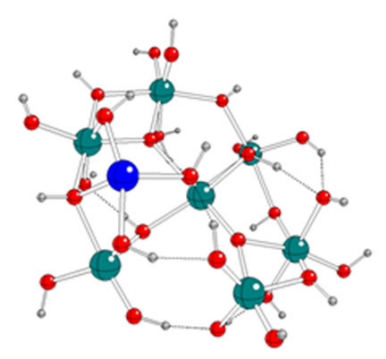

II-A2a

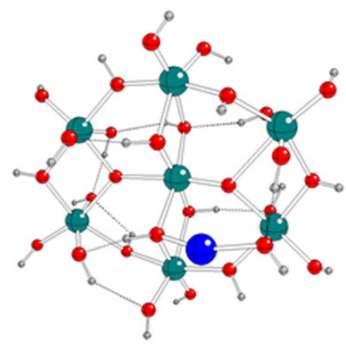

II-A2b

Fig. 5. B3LYP optimized geometries of ${ }^{2}\left[\mathrm{Ti}_{7} \mathrm{O}_{28} \mathrm{H}_{26} \mathrm{Cu}\right]^{0}$ model systems (see Fig. 1 for atom notations) (Breza and Šimon, 2020). 


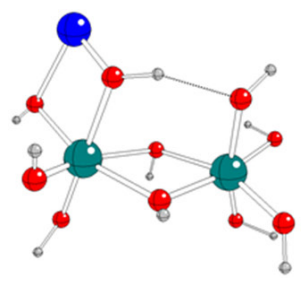

II-B la

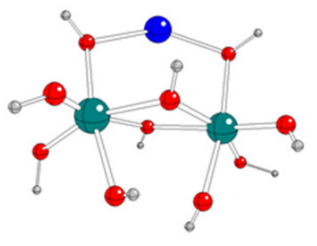

II-B $1 b$

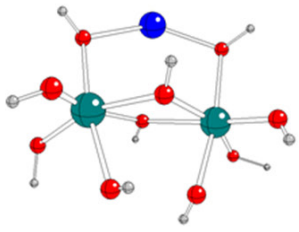

II-B $1 \mathrm{c}$

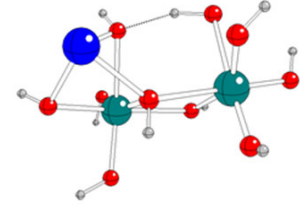

II-B2a

Fig. 6. B3LYP optimized geometries of ${ }^{2}\left[\mathrm{Ti}_{2} \mathrm{O}_{10} \mathrm{H}_{10} \mathrm{Cu}\right]^{0}$ model systems (see Fig. 1 for atom notations) (Breza and Šimon, 2020).

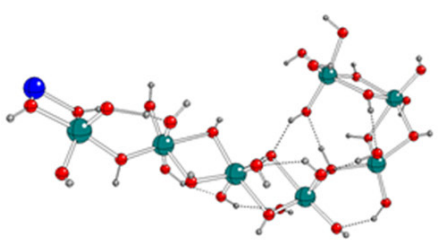

II-C1a

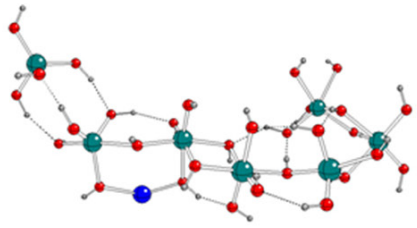

II-C1d

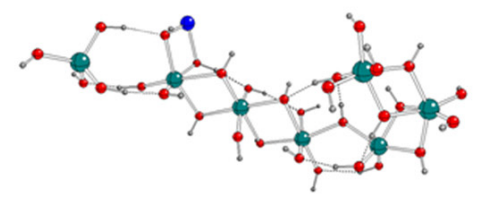

II-C1b

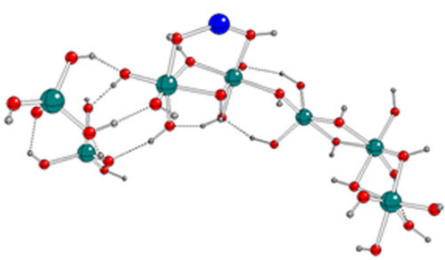

II-C1e

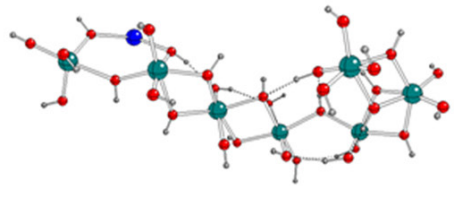

II-C1c

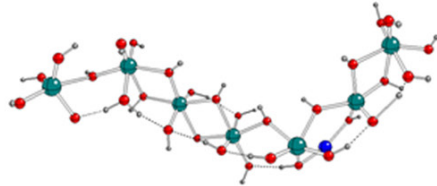

II-C.1f

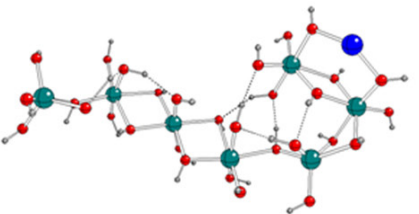

II-C. 19

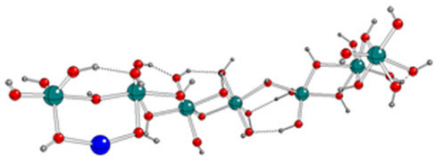

II-C2a

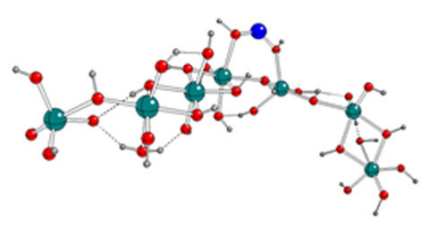

II-C2d

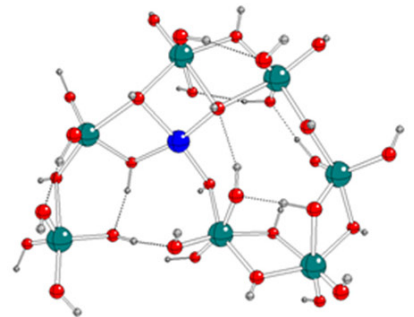

II-C2b

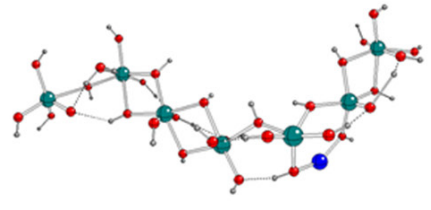

II-C2e

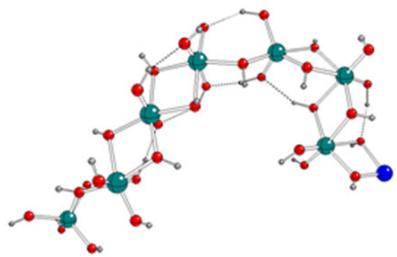

II-C1h

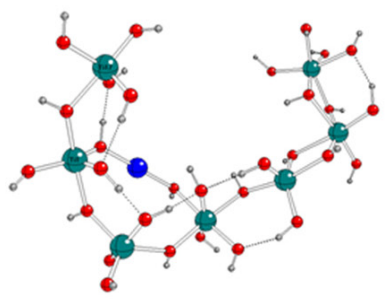

II-C2C

Fig. 7. B3LYP optimized geometries of ${ }^{2}\left[\mathrm{Ti}_{7} \mathrm{O}_{30} \mathrm{H}_{30} \mathrm{Cu}\right]^{0}$ model systems (see Fig. 1 for atom notations) (Breza and Šimon, 2020). 

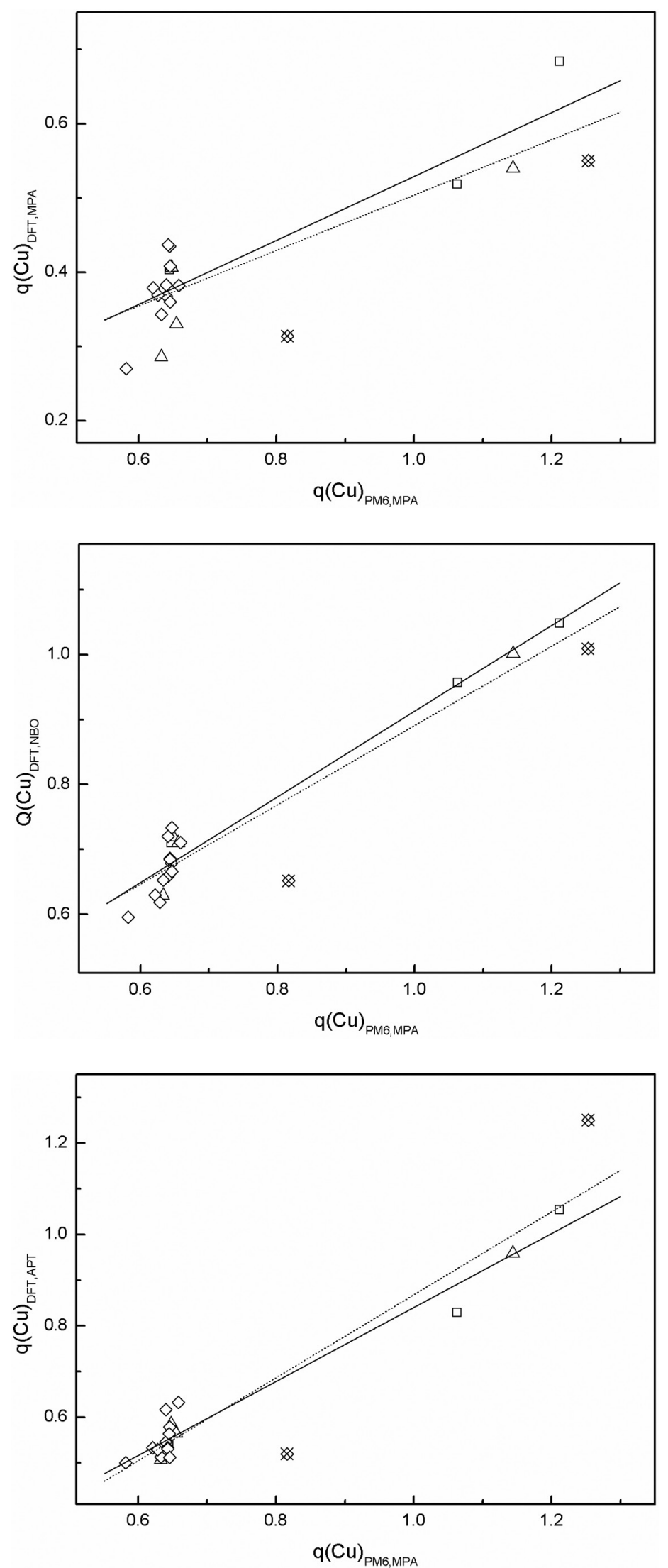

Fig. 8. Plots of MPA (top), NBO (middle) and APT (bottom) charges of Cu obtained by the DFT-B3LYP method vs MPA charges of $\mathrm{Cu}$ obtained by the PM6 method for ${ }^{2}\left[\mathrm{Ti}_{7} \mathrm{O}_{28} \mathrm{H}_{26} \mathrm{Cu}\right]^{0}$ (squares), ${ }^{2}\left[\mathrm{Ti}_{2} \mathrm{O}_{10} \mathrm{H}_{10} \mathrm{Cu}\right]^{0}$ (triangles), and ${ }^{2}\left[\mathrm{Ti}_{7} \mathrm{O}_{30} \mathrm{H}_{30} \mathrm{Cu}\right]^{0}$ (diamonds) systems. Dashed and full lines correspond to linear regression for all systems and for all but II-C1e and II-C2b systems (crossed diamonds), respectively. 


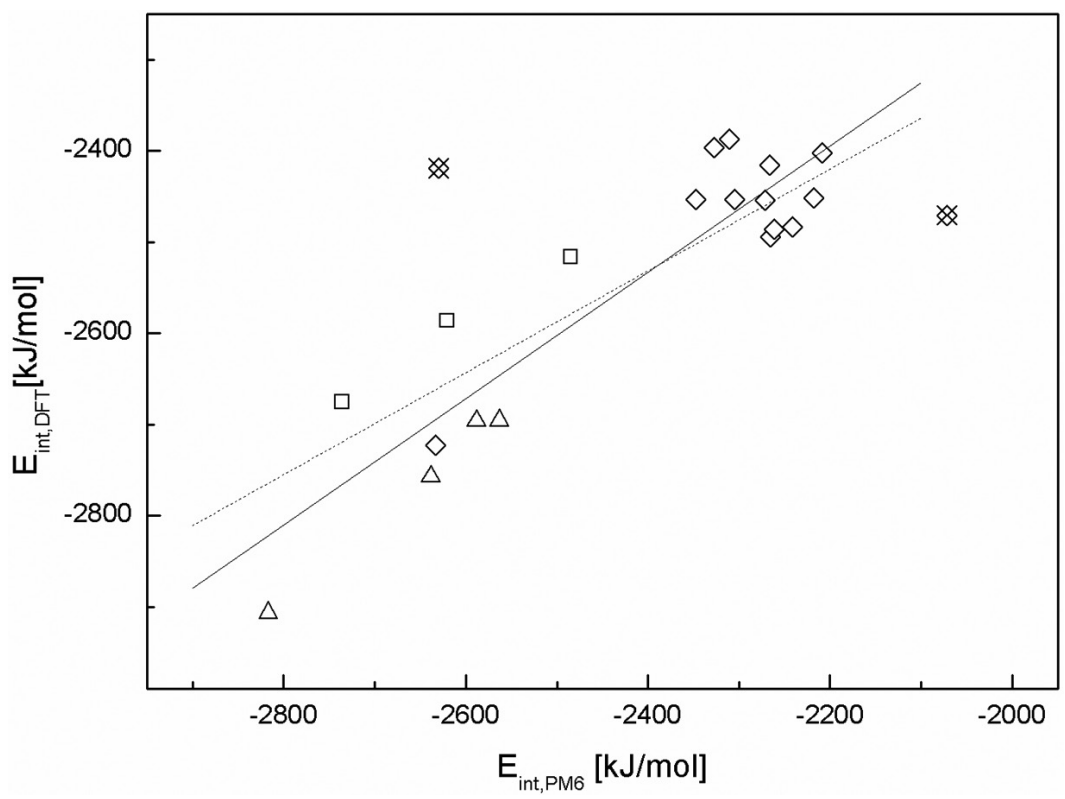

Fig. 9. Plot of interaction energies obtained by the DFT-B3LYP method vs the PM6 method for ${ }^{2}\left[\mathrm{Ti}_{7} \mathrm{O}_{28} \mathrm{H}_{26} \mathrm{Cu}\right]^{0}$ (squares), ${ }^{2}\left[\mathrm{Ti}_{2} \mathrm{O}_{10} \mathrm{H}_{10} \mathrm{Cu}\right]^{0}$ (triangles), and ${ }^{2}\left[\mathrm{Ti}_{7} \mathrm{O}_{30} \mathrm{H}_{30} \mathrm{Cu}\right]^{0}$ (diamonds) systems. Dashed and full lines correspond to linear regression for all systems and for all but II-C1e and II-C2b systems (crossed diamonds), respectively.

Tab. 2. Regression parameters $\left(\mathrm{a}_{1}, \mathrm{a}_{0}\right)$ of Eq. (2) with standard deviations for model systems II (see Figs. $5-7)$ and the coefficient of determination $\left(\mathrm{R}^{2}\right)$ for the dataset consisting of $\mathrm{N}$ components.

\begin{tabular}{|c|c|c|c|c|c|}
\hline $\mathrm{N}$ & $\mathrm{Y}$ & $\mathrm{X}$ & $a_{1}$ & $\mathrm{a}_{0}$ & $\mathrm{R}^{2}$ \\
\hline \multirow[t]{4}{*}{21} & $\mathrm{q}(\mathrm{Cu})_{\mathrm{DFT}, \mathrm{MPA}}$ & $\mathrm{q}(\mathrm{Cu})_{\mathrm{PM} 6, \mathrm{MPA}}$ & $0.373 \pm 0.058$ & $0.131 \pm 0.045$ & 0.66689 \\
\hline & $\mathrm{q}(\mathrm{Cu})_{\mathrm{DFT}, \mathrm{APT}}$ & $\mathrm{q}(\mathrm{Cu})_{\mathrm{PM} 6, \mathrm{MPA}}$ & $0.908 \pm 0.069$ & $-0.040 \pm 0.054$ & 0.89601 \\
\hline & $\mathrm{q}(\mathrm{Cu})_{\mathrm{DFT}, \mathrm{NBO}}$ & $\mathrm{q}(\mathrm{Cu})_{\mathrm{PM} 6, \mathrm{MPA}}$ & $0.610 \pm 0.046$ & $0.281 \pm 0.035$ & 0.89888 \\
\hline & $\mathrm{E}_{\mathrm{int}, \mathrm{DFT}}$ & $\mathrm{E}_{\mathrm{int}, \mathrm{PM} 6}$ & $0.559 \pm 0.097$ & $-1190 \pm 230^{b)}$ & 0.61929 \\
\hline \multirow[t]{4}{*}{$19^{\mathrm{a})}$} & $\mathrm{q}(\mathrm{Cu})_{\mathrm{DFT}, \mathrm{MPA}}$ & $\mathrm{q}(\mathrm{Cu})_{\mathrm{PM} 6, \mathrm{MPA}}$ & $0.431 \pm 0.059$ & $0.098 \pm 0.044$ & 0.74127 \\
\hline & $\mathrm{q}(\mathrm{Cu})_{\mathrm{DFT}, \mathrm{APT}}$ & $\mathrm{q}(\mathrm{Cu})_{\mathrm{PM} 6, \mathrm{MPA}}$ & $0.809 \pm 0.044$ & $0.031 \pm 0.033$ & 0.94896 \\
\hline & $\mathrm{q}(\mathrm{Cu})_{\mathrm{DFT}, \mathrm{NBO}}$ & $\mathrm{q}(\mathrm{Cu})_{\mathrm{PM} 6, \mathrm{MPA}}$ & $0.659 \pm 0.038$ & $0.254 \pm 0.029$ & 0.94190 \\
\hline & $\mathrm{E}_{\mathrm{int}, \mathrm{DFT}}$ & $\mathrm{E}_{\mathrm{int}, \mathrm{PM} 6}$ & $0.693 \pm 0.075$ & $-870 \pm 180^{b)}$ & 0.82382 \\
\hline
\end{tabular}

Remarks:

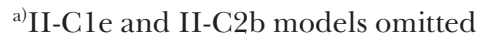

b) in $\mathrm{kJ} / \mathrm{mol}$ units

ing hydroxyl (models II-B2a, and II-C2a to II-C2f) groups, respectively (see Figs. 6-7).

Copper atomic charges and interaction energies of model systems II (Figs. 5-7) are presented in Figs. 8-9 and Table A2 of Appendix. Results for II-C1e and II-C2b model systems significantly differ from the remaining ${ }^{2}\left[\mathrm{Ti}_{7} \mathrm{O}_{30} \mathrm{H}_{30} \mathrm{Cu}\right]^{0}$ ones. Thus, results of the linear regression according to Eq. (2) are presented for all model systems II and the two above mentioned model systems were omitted (Table 2, Figs. 8-9).

$\mathrm{Cu}$ charges obtained by the DFT-B3LYP method using $\mathrm{NBO}$ and APT treatment increase with their increasing counterparts obtained by the PM6 method with fairly good statistical parameters, especially by omitting the data for II-Cle and II-C2b systems (Table 2, Fig. 8). Nevertheless, significantly worse statistical parameters for the MPA charges obtained by the DFT-B3LYP were obtained.

Slightly worse results (despite the improvement after II-C1e and II-C2b systems omitting) were obtained for interaction energies (Table 2, Fig. 9).

\section{c) All model systems}

Despite the 6-311G* basis sets used in the B3LYP calculations of model II systems (Breza and Šimon, 2019), unlike the LANL2DZ ones used in 

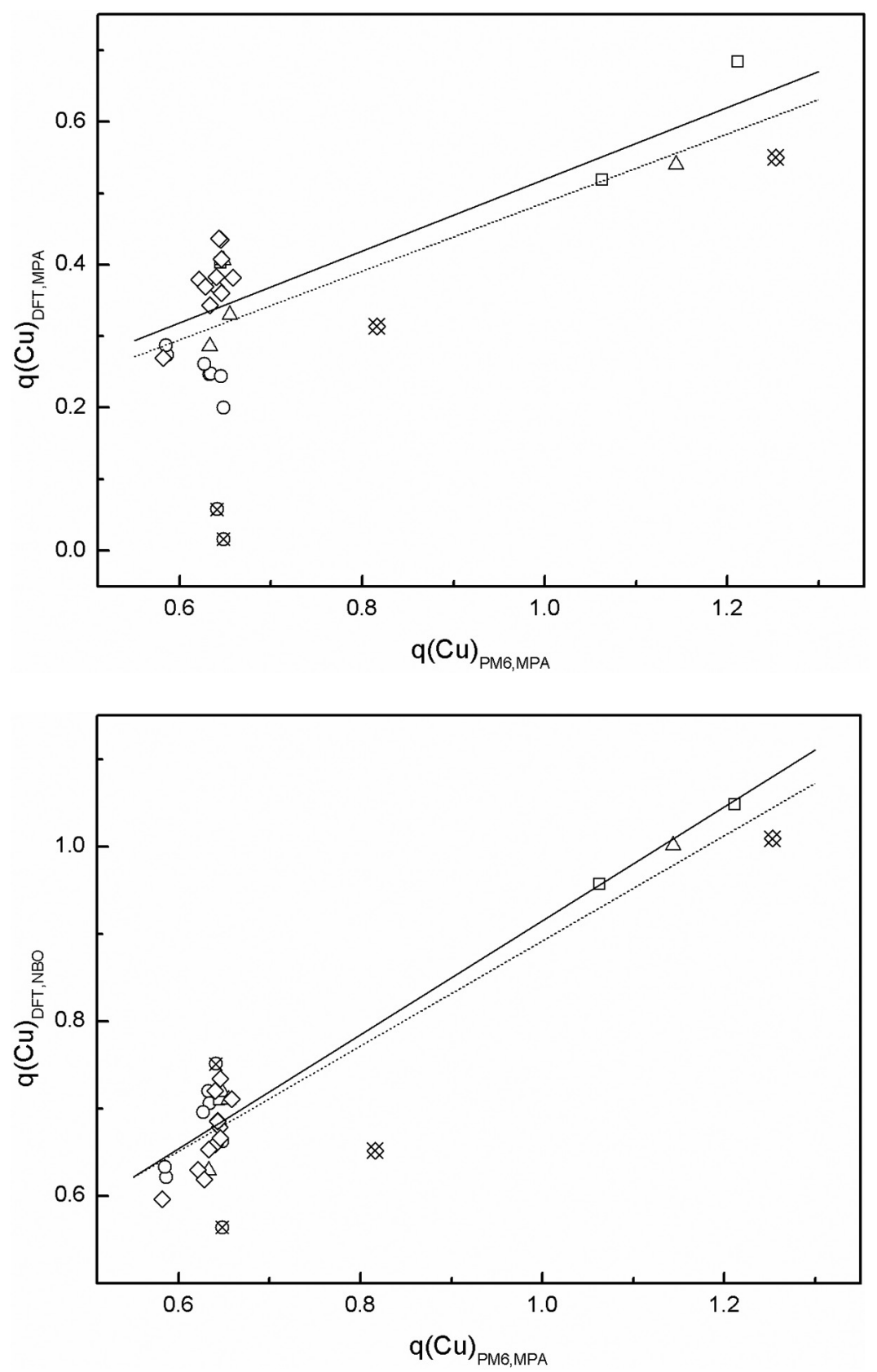

Fig. 10. Plots of MPA (top) and NBO (bottom) charges of $\mathrm{Cu}$ obtained by the DFT-B3LYP method vs MPA charges of $\mathrm{Cu}$ obtained by the PM6 method for ${ }^{2}\left[\mathrm{Ti}_{40} \mathrm{O}_{124} \mathrm{H}_{81} \mathrm{Cu}\right]^{5-}$ (circles), ${ }^{2}\left[\mathrm{Ti}_{7} \mathrm{O}_{28} \mathrm{H}_{26} \mathrm{Cu}\right]^{0}$ (squares), ${ }^{2}\left[\mathrm{Ti}_{2} \mathrm{O}_{10} \mathrm{H}_{10} \mathrm{Cu}\right]^{0}$ (triangles), and ${ }^{2}\left[\mathrm{Ti}_{7} \mathrm{O}_{30} \mathrm{H}_{30} \mathrm{Cu}\right]^{0}$ (diamonds) systems. Dashed and full lines correspond to linear regression for all systems and for all but I-B3, I-C2 (crossed circles), II-C1e and

II-C2b systems (crossed diamonds), respectively.

this study for model I systems (we were not able to use better basis sets due to technical reasons), correlation of the DFT and PM6 results was attempted for all systems (Table 3, Figs. 10-11). Surprisingly, statistical parameters for $\mathrm{Cu}$ charges obtained by the NBO treatment as well as interaction energies (with or without some data omitting) are surprisingly good and indicate linear dependence of the PM6 and DFT results.
Only statistical parameters for the MPA charges obtained by the DFT-B3LYP method are significantly worse.

\section{Conclusions}

The relation between $\mathrm{Cu}$ atomic charges has been investigated in terms of MPA, NBO and APT treatments as well as interaction energies obtained 


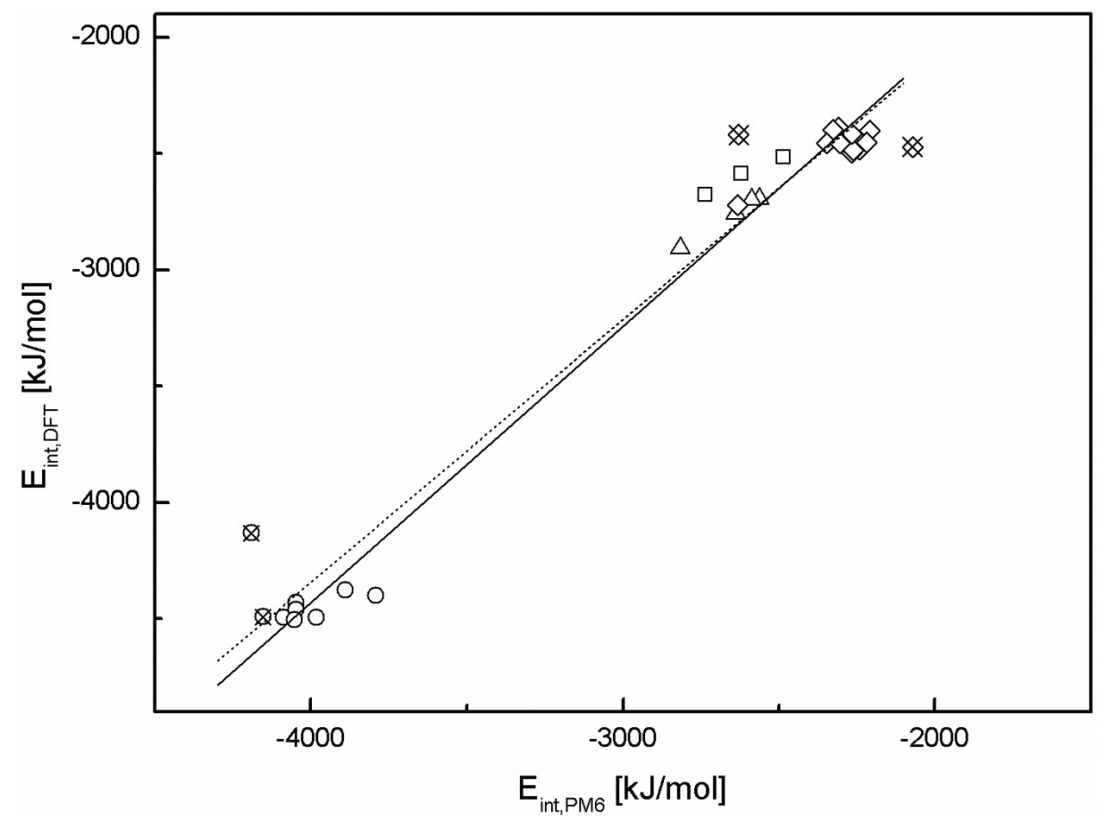

Fig. 11. Plot of interaction energies obtained by the DFT-B3LYP method vs the PM6 method for ${ }^{2}\left[\mathrm{Ti}_{40} \mathrm{O}_{124} \mathrm{H}_{81} \mathrm{Cu}\right]^{5-}$ (circles), ${ }^{2}\left[\mathrm{Ti}_{7} \mathrm{O}_{28} \mathrm{H}_{26} \mathrm{Cu}\right]^{0}$ (squares), ${ }^{2}\left[\mathrm{Ti}_{2} \mathrm{O}_{10} \mathrm{H}_{10} \mathrm{Cu}\right]^{0}$ (triangles), and ${ }^{2}\left[\mathrm{Ti}_{7} \mathrm{O}_{30} \mathrm{H}_{30} \mathrm{Cu}\right]^{0}$ (diamonds) systems. Dashed and full lines correspond to linear regression for all systems and for all but I-B3, I-C2 (crossed circles), II-C1e and II-C2b systems (crossed diamonds), respectively.

Tab. 3. Regression parameters $\left(a_{1}, a_{0}\right)$ of Eq. (2) with standard deviations for model systems I and II (see Figs. 1, 5-7) and the coefficient of determination $\left(\mathrm{R}^{2}\right)$ for the dataset consisting of $\mathrm{N}$ components.

\begin{tabular}{|c|c|c|c|c|c|}
\hline $\mathrm{N}$ & $\mathrm{Y}$ & $\mathrm{X}$ & $a_{1}$ & $\mathrm{a}_{0}$ & $\mathrm{R}^{2}$ \\
\hline \multirow[t]{3}{*}{30} & $\mathrm{q}(\mathrm{Cu})_{\mathrm{DFT}, \mathrm{MPA}}$ & $\mathrm{q}(\mathrm{Cu})_{\mathrm{PM} 6, \mathrm{MPA}}$ & $0.48 \pm 0.10$ & $0.007 \pm 0.075$ & 0.42101 \\
\hline & $\mathrm{q}(\mathrm{Cu})_{\mathrm{DFT}, \mathrm{NBO}}$ & $\mathrm{q}(\mathrm{Cu})_{\mathrm{PM} 6, \mathrm{MPA}}$ & $0.602 \pm 0.047$ & $0.290 \pm 0.034$ & 0.84992 \\
\hline & $\mathrm{E}_{\mathrm{int}, \mathrm{DFT}}$ & $\mathrm{E}_{\mathrm{int}, \mathrm{PM} 6}$ & $1.130 \pm 0.040$ & $176 \pm 120^{c)}$ & 0.96452 \\
\hline \multirow[t]{3}{*}{$28^{\text {a) }}$} & $\mathrm{q}(\mathrm{Cu})_{\mathrm{DFT}, \mathrm{MPA}}$ & $\mathrm{q}(\mathrm{Cu})_{\mathrm{PM} 6, \mathrm{MPA}}$ & $0.439 \pm 0.070$ & $0.055 \pm 0.052$ & 0.58896 \\
\hline & $\mathrm{q}(\mathrm{Cu})_{\mathrm{DFT}, \mathrm{NBO}}$ & $\mathrm{q}(\mathrm{Cu})_{\mathrm{PM}, \mathrm{MPA}}$ & $0.600 \pm 0.041$ & $0.293 \pm 0.030$ & 0.88880 \\
\hline & $\mathrm{E}_{\mathrm{int}, \mathrm{DFT}}$ & $\mathrm{E}_{\mathrm{int}, \mathrm{PM} 6}$ & $1.176 \pm 0.040$ & $290 \pm 120^{c)}$ & 0.97032 \\
\hline \multirow[t]{3}{*}{$26^{\mathbf{b})}$} & $\mathrm{q}(\mathrm{Cu})_{\mathrm{DFT}, \mathrm{MPA}}$ & $\mathrm{q}(\mathrm{Cu})_{\mathrm{PM} 6, \mathrm{MPA}}$ & $0.502 \pm 0.081$ & $0.018 \pm 0.058$ & 0.59683 \\
\hline & $\mathrm{q}(\mathrm{Cu})_{\mathrm{DFT}, \mathrm{NBO}}$ & $\mathrm{q}(\mathrm{Cu})_{\mathrm{PM} 6, \mathrm{MPA}}$ & $0.652 \pm 0.037$ & $0.263 \pm 0.026$ & 0.92650 \\
\hline & $\mathrm{E}_{\mathrm{int, \textrm {DFT }}}$ & $\mathrm{E}_{\text {int,PM6 }}$ & $1.188 \pm 0.031$ & $321 \pm 91^{\mathrm{c})}$ & 0.98314 \\
\hline
\end{tabular}

Remarks:

a) I-B4 and I-C2 models omitted

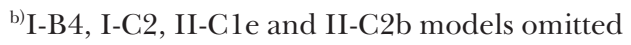

c) in $\mathrm{kJ} / \mathrm{mol}$ units

by the PM6 and DFT-B3LYP methods. Unfortunately, Gaussian software refuses to evaluate NBO charges for semiempirical methods. Moreover, APT charges require vibrational analysis for optimized geometries. Despite these restrictions, our results indicate linear dependence between the $\mathrm{Cu}$ charges (except for the DFT-B3LYP ones) and interaction energies obtained by both methods. Nevertheless, this conclusion assumes data evaluated with standard accuracy. Our results confirm lower reliability of MPA charges for DFT methods (unlike the semiempirical ones) which is well known.

\section{Acknowledgements}

This study has received funding from the European Union's Horizon 2020 research and innovation program under grant agreement No. 685817 (HISENTS). The author thanks the HPC center at the Slovak University of Technology in Bratislava, which is a part of the Slovak Infrastructure of High Performance Computing (SIVVP Project ITMS 26230120002, funded by the European Region Development Funds) for providing computing facilities. The Ministry of Education, Science, Research and Sport of the Slovak Republic is appreciated for funding within the scheme 'Excellent research teams'. 


\section{Appendix}

Tab. A1. Copper atomic charges, $\mathrm{q}(\mathrm{Cu})_{\mathrm{M}, \mathrm{P}}$, and interaction energies, $\mathrm{E}_{\mathrm{int}, \mathrm{M}}$, for model systems I (Fig. 1) obtained by M = PM6 (Breza and Šimon, 2019) or DFT (this study) methods and P = MPA, APT or NBO population analyses.

\begin{tabular}{lcccccc}
\hline Model & $\mathrm{q}(\mathrm{Cu})_{\mathrm{PM} 6, \mathrm{MPA}}$ & $\mathrm{q}(\mathrm{Cu})_{\mathrm{PM} 6, \mathrm{APT}}$ & $\mathrm{E}_{\text {int,PM6 }}[\mathrm{kJ} / \mathrm{mol}]$ & $\mathrm{q}(\mathrm{Cu})_{\mathrm{DFT}, \mathrm{MPA}}$ & $\mathrm{q}(\mathrm{Cu})_{\mathrm{DFT}, \mathrm{NBO}}$ & $\mathrm{E}_{\text {int, DFT }}[\mathrm{kJ} / \mathrm{mol}]$ \\
\hline I-A & 0.586 & 0.669 & -3789.9 & 0.274 & 0.621 & -4400.7 \\
I-B1 & 0.585 & 0.638 & -3888.6 & 0.287 & 0.633 & -4376.8 \\
I-B2 & 0.633 & 0.721 & -4046.8 & 0.247 & 0.72 & -4430.3 \\
I-B3 & 0.648 & 0.744 & -4190.3 & 0.016 & 0.564 & -4131.3 \\
I-B4 & 0.634 & 0.734 & -4086.5 & 0.248 & 0.706 & -4494.6 \\
I-B5 & 0.648 & 0.721 & -4047.2 & 0.200 & 0.662 & -4459.9 \\
I-B6 & 0.645 & 0.740 & -3981.1 & 0.244 & 0.719 & -4493.4 \\
I-C1 & 0.627 & 0.739 & -4053.0 & 0.261 & 0.696 & -4505.3 \\
I-C2 & 0.641 & 0.899 & -4152.6 & 0.058 & 0.751 & -4492.7 \\
\hline
\end{tabular}

Tab. A2. Copper atomic charges, $\mathrm{q}(\mathrm{Cu})_{\mathrm{M}, \mathrm{P}}$, and interaction energies, $\mathrm{E}_{\mathrm{int}, \mathrm{M}}$, for model systems II (Figs. 4-6) obtained by M = DFT (Breza and Šimon, 2020) or PM6 (this study) methods and P = MPA, APT or NBO population analyses.

\begin{tabular}{lcccccc}
\hline Model & $\mathrm{q}(\mathrm{Cu})_{\mathrm{DFT}, \mathrm{MPA}}$ & $\mathrm{q}(\mathrm{Cu})_{\mathrm{DFT}, \mathrm{APT}}$ & $\mathrm{q}(\mathrm{Cu})_{\mathrm{DFT}, \mathrm{NBO}}$ & $\mathrm{E}_{\text {int,DFT }}[\mathrm{kJ} / \mathrm{mol}]$ & $\mathrm{q}(\mathrm{Cu})_{\mathrm{PM} 6, \mathrm{MPA}}$ & $\mathrm{E}_{\text {int,PM6 }}[\mathrm{kJ} / \mathrm{mol}]$ \\
\hline II-A1a & 0.518 & 0.829 & 0.957 & -2586.4 & 1.063 & -2620.3 \\
II-A2a & 0.684 & 1.054 & 1.048 & -2675.8 & 1.212 & -2735.5 \\
II-A2b & 0.403 & 0.541 & 0.710 & -2516.5 & 0.645 & -2484.4 \\
II-B1a & 0.406 & 0.585 & 0.719 & -2695.6 & 0.648 & -2563.0 \\
II-B1b & 0.286 & 0.507 & 0.629 & -2757.2 & 0.633 & -2638.3 \\
II-B1c & 0.540 & 0.959 & 1.001 & -2906.6 & 1.144 & -2816.8 \\
II-B2a & 0.330 & 0.565 & 0.710 & -269.06 & 0.655 & -2588.4 \\
II-C1a & 0.382 & 0.632 & 0.711 & -2401.9 & 0.658 & -2208.5 \\
II-C1b & 0.408 & 0.579 & 0.734 & -2483.4 & 0.646 & -2241.5 \\
II-C1c & 0.368 & 0.546 & 0.659 & -2387.1 & 0.64 & -2310.4 \\
II-C1d & 0.379 & 0.533 & 0.630 & -2396.9 & 0.621 & -2327.8 \\
II-C1e & 0.314 & 0.520 & 0.652 & -2470.5 & 0.816 & -2071.5 \\
II-C1f & 0.437 & 0.533 & 0.686 & -2453.9 & 0.643 & -2271.1 \\
II-C1g & 0.343 & 0.513 & 0.653 & -2494.4 & 0.633 & -2265.6 \\
II-C1h & 0.383 & 0.617 & 0.720 & -2451.8 & 0.640 & -2217.8 \\
II-C2a & 0.369 & 0.529 & 0.619 & -2453.7 & 0.628 & -2347.1 \\
II-C2b & 0.550 & 1.250 & 1.009 & -2419.1 & 1.253 & -2629.8 \\
II-C2c & 0.270 & 0.500 & 0.596 & -2722.8 & 0.582 & -2632.8 \\
II-C2d & 0.435 & 0.564 & 0.679 & -2453.6 & 0.645 & -2305 \\
II-C2e & 0.437 & 0.531 & 0.685 & -2486.5 & 0.643 & -2261.4 \\
II-C2f & 0.360 & 0.512 & 0.666 & -2415.6 & 0.646 & -2266.7 \\
\hline
\end{tabular}

\section{References}

Alagona G, Ghio C (2009a) Antioxidant Properties of Pterocarpans through Their Copper(II) Coordination Ability. A DFT Study in Vacuo and in Aqueous Solution. J Phys Chem. A 113: 15206-15216.

Alagona G, Ghio C (2009b) Plicatin B conformational landscape and affinity to copper (I and II) metal cations. A DFT study. Phys Chem Chem Phys 11: $776-790$.
Becke AD (1993) Density-functional thermochemistry 3. The role of exact exchange. J Chem Phys 98: 5648-5652.

Breza M, Šimon P (2019) Quantum-chemical studies of rutile nanoparticles toxicity I. Defect-free rod-like model clusters. Acta Chim Slovaca 12: 168-174.

Breza M, Simon P (2020) On shape dependence of the toxicity of rutile nanoparticles. J Nanopart Res (2020) 22: 0058.

Cioslowski J (1989) A new population analysis based on atomic polar tensors. J Am Chem Soc 111: 8333-8336. 
Dunning Jr TH, Hay PJ (1977) Gaussian Basis Sets for Molecular Calculations, in Modern Theoretical Chemistry, (Ed. Schaefer HF III), Vol. 3, Plenum, New York, pp. 1-28.

Frisch MJ, Trucks GW, Schlegel HB, Scuseria GE, Robb MA, Cheeseman JR et al. (2009) Gaussian 09, Revision D.01, Gaussian Inc., Wallingford, CT.

Forest V, Leclerc L, Hochepie JF, Trouvé A, Sarry G, Pourchez J (2017) Impact of cerium oxide nanoparticles shape on their in vitro cellular toxicity. Toxicol Vitro 38: 136-141.

Hay PJ, Wadt WR (1985) Ab initio effective core potentials for molecular calculations - potentials for the transition-metal atoms Sc to $\mathrm{Hg}$. J Chem Phys 82: 270-283.

Hsiao I-L, Huang Y-J (2011) Effects of various physicochemical characteristics on the toxicities of $\mathrm{ZnO}$ and $\mathrm{TiO}$ nanoparticles toward human lung epithelial cells. Sci Total Environ 409: 1219-1228.

Huang Y-W, Cambre M, Lee H-J (2017) The toxicity of nanoparticles depends on multiple molecular and physicochemical mechanisms. Int J Mol Sci 18: 2702.

Jelemenská I, Breza M (2021) Comparative DFT study of the effectiveness of p-phenylenediamine antioxidants through their coordination ability towards the late $1^{\text {st }}$ row transition metals. Polym. Degrad. Stab. 183: 109438.

Lee JH, Ju JE, Kim BI, Pak PJ, Choi EK, Lee HS, Chung N (2014) Rod-shaped iron oxide nanoparticles are more toxic than sphere-shaped nanoparticles to murine macrophage cells. Environ Toxicol Chem 33: 2759-2766.
Mammino L (2013) Investigation of the antioxidant properties of hyperjovinol A through its $\mathrm{Cu}$ (II) coordination ability. J Mol Model 19: 2127-2142.

Mulliken RS (1955) Electronic Population Analysis on LCAO-MO Molecular Wave Functions I. J Chem Phys 23: $1833-1840$

Puškárová I, Breza M (2016) DFT studies of the effectiveness of p-phenylenediamine antioxidants through their $\mathrm{Cu}(\mathrm{II})$ coordination ability. Polym Degrad Stab 128: 15-21.

Puškárová I, Breza M (2017) DFT studies of the effectiveness of p-substituted diphenyl amine antioxidants in styrene-butadiene rubber through their $\mathrm{Cu}(\mathrm{II})$ coordination ability. Chem Phys Lett 680: 78-82.

Reed AE, Curtiss LA, Weinhold F (1988) Intermolecular interactions from a natural bond orbital, donoracceptor viewpoint. Chem Rev 88: 899-926.

Stewart JJP (2007) Optimization of parameters for semiempirical methods. V. Modification of NDDO approximations and application to 70 elements. J Mol Model 13: 1173-1213.

Tsiepe TJ, Kabanda M, Serobatse KRN (2015) Antioxidant Properties of Kanakugiol Revealed Through the Hydrogen Atom Transfer, Electron Transfer and $\mathrm{M}^{2+}\left(\mathrm{M}^{2+}=\mathrm{Cu}(\mathrm{II})\right.$ or $\mathrm{Co}(\mathrm{II})$ Ion) Coordination Ability Mechanisms. A DFT Study In Vacuo and in Solution. Food Biophys 10: 342-359. 